\title{
Marketinški pristop v izobraževanju odraslih
}

\author{
Daniela Brečko
}

\begin{abstract}
Marketing je v svetu in vse bolj tudi pri nas osrednja aktivnost sodobnih izobraževalnih institucij. Izobraževalne institucije, ki želijo uspeti in preživeti, morajo dobro poznati svoj trg, svoje uporabnike, njihove potrebe in pričakovanja, kajti le tako bodo pravočasno prilagajale, posodabljale in razvijale nove izobraževalne programe.
\end{abstract}

$\mathrm{Z}$ marketingom imamo danes opraviti skoraj na vseh področjih človekovega delovanja, torej tudi v izobraževalnih institucijah. Najbolj aktivno marketinško delovanje je opaziti predvsem v zasebnih izobraževalnih organizacijah za odrasle. To pa še ne pomeni, da marketinško ne delujejo tudi druge izobraževalne institucije, od vzgojnovarstvenih zavodov, osnovnih in srednjih šol do fakultet. Na to le malokdo pomisli, pa tudi na to, kaj marketing $\mathrm{v}$ resnici sploh je in kakšne aktivnosti se skrivajo za tem izrazom. V zvezi s pojmom marketing je veliko zablod in stereotipov. Pri nas ta izraz še vedno najpogosteje pojmujemo preozko, razumemo ga kot prodajanje, oglaševanje, stike $\mathrm{z}$ javnostmi itd., skratka kot nekaj, kar je značilno za poslovni svet, industrijo in trgovino. Zaradi takšnega pojmovanja marketing le s težavo povezujemo z izobraževalnimi ustanovami.

Namen pričujoče razprave je opredeliti pojem in vlogo marketinga v izobraževanju odraslih in odgovoriti na vprašanje, zakaj je marketing danes na tem področju potreben. Poskusila bom prikazati poglavitne elemente marketinga $v$ izobraževalnih institucijah za odrasle in predstaviti najpogostejše načine komuniciranja izobraževalne ustanove $\mathrm{z}$ različnimi javnostmi.

\section{Kåj je marketing}

Veliko ljudi gleda na izraz marketing negativno, ker so prepričani, da je posledica marketinškega delovanja to, da ljudje kupujejo stvari, ki si jih ne želijo oziroma jih ne potrebujejo, in še celo več, da kupujejo stvari, ki si jih s svojim zaslužkom ne morejo privoščiti. Kupci naj bi bili torej pravzaprav žrtve marketinga. Izobraževalci, ki najpogosteje niso vajeni marketinškega izrazoslovja in marketinški proces slabo poznajo, so prav tako v velikem številu prepričani, da izobraževalne institucije ne potrebujejo marketinškega pristopa. V zvezi s tem lahko najbrž izvzamemo predvsem zasebne izobraževalne organizacije, ki marketinški pristop uporabljajo že od vsega začetka delovanja in bi bile brez marketinških aktivnosti kaj kmalu prisiljene, da prenehajo delovati. Odklanjanje in kritiziranje marketinških aktivnosti pri izobraževalnih storitvah bi na splošno lahko razdelili $v$ dve smeri:

1. Marketinška dejavnost je v nasprotju z izobraževalnim poslanstvom. Nekateri izobraževalci verjamejo, da je marketing primeren le za pridobitno usmerjena podjetja, za tako imenovani poslovni svet, in da izobraževalno delo pomeni več kot le »posel«. Vrednote in metode izobraževalnih organizacij naj bi bile v neposrednem nasprotju $\mathrm{z}$ vrednotami in metodami v podjetništvu. Cilj izobraževanja naj bi bil na eni strani posredovanje celo- vitega znanja in privzgojitev sposobnosti analitičnega in racionalnega mišljenja, na drugi strani pa naj bi z manipulativnimi metodami in tehnikami zaslužili čim več denarja.

2. Marketing v izobraževanju ni potreben. Tako mislijo v vseh tistih institucijah, ki zaenkrat še prejemajo dovolj finančne pomoči od države oziroma občin in se še ne srečujejo $z$ upadom pri vpisu ter s finančnimi težavami.

Omenjene kritike so bolj ali manj neupravičene in v njih lahko vidimo predvsem nerazumevanje in slabo poznavanje marketinga.

Kaj sploh pomeni pojem marketing? Vprašanje so leta 1985 zastavili tristotim izobraževalnim institucijam v ZDA, ki so bile $v$ recesiji in so se srečevale $z$ upadajočim številom udeležencev ter naraščajočimi stroški. Enainšestdeset odstotkov jih je odgovorilo, da je marketing kombinacija prodaje, oglaševanja in odnosov z javnostmi. Osemindvajset odstotkov pa jih je odgovorilo, da marketing pomeni le eno izmed teh treh aktivnosti. Le manjši del vprašanih je vedel, da je marketinško delo povezano $\mathrm{z}$ ocenjevanjem in ugotavljanjem potreb, z marketinškimi raziskavami, razvojem novih programov, določanjem primerne cene (šolnine, kotizacije) ter z informiranjem (Kotler, 1985, str. 6).

Pri nas so danes razmere podobne kot pred dobrimi desetimi leti v ZDA. Večina ljudi misli, da je marketing sinonim za prodajo in promocijo, kar ni nič čudnega, saj živimo v času, ko nas zasipavajo $\mathrm{z}$ različnimi televizijskimi reklamami, s časopisnimi oglasi, zaradi nasilnih prodajalcev, ki prodajajo po načelu »door to door «, pa previdneje odpiramo vrata svojega doma. Toda prodaja še zdaleč ni najpomembnejši del marketinga.

Najenostavnejšo definicijo marketinga najdemo v delu G. Morella, ki meni, da marketing definiramo kot sistem, ki je usmerjen $\mathrm{v}$ zadovoljevanje človekovih potreb in hotenj z organiziranim menjalnim procesom, ki temelji na transakciji (Morello, 1993, str. 4).

Osrednji koncept marketinga je menjava. Menjava med posamezniki, skupinami, institucijami itd. Izobraževalna institucija razpiše nov in zelo zanimiv izobraževalni program, v katerega se vpišejo zainteresirani posamezniki. Obe strani se strinjata $z$ menjavo. Institucija ponuja novo znanje, posamezniki pa to storitev plačajo.

Za potrebe izobraževalnih institucij je zato primernejša Kotlerjeva definicija marketinga: »Marketing je analiziranje, planiranje, uresničevanje in nadzor nad skrbno pripravljenimi programi, oblikovan tako, da doprinese $\mathrm{k}$ prostovoljni menjavi vrednosti s ciljnim tržiščem z namenom, da se dosežejo cilji institucije. Marketing se ukvarja $\mathrm{z}$ oblikovanjem izobraževalne ponudbe (določene institucije - op. avtorice), ki mora zadovoljevati tržne 
potrebe in želje, pri tem pa mora vsebovati in uporabljati učinkovito cenovno politiko, komunikacijo in distribucijo $\mathrm{z}$ namenom informiranja, motiviranja in svetovanja potencialnim udeležencem.« (Kotler, 1985, str. 7)

Iz definicije jasno razberemo, da imamo $\mathrm{z}$ marketingom opraviti tudi v celotnem izobraževalnem sistemu, in to že dolgo časa, le da ga nismo tako imenovali. Značilen primer so šolske proslave ali proslave, ki jih prirejajo v vrtcih, pri tem pa povabijo starše ter občinske veljake. Lahko bi jih označili kot »prodajanje « šole oziroma vrtca, in sicer staršem, morebitnim staršem, in kot prizadevanje za pozitivno podobo kraja ter morebiti kot pridobivanje dodatnih sredstev $\mathrm{z}$ donacijami in s sponzorstvom. Iz definicije pa tudi razberemo, da je marketing proces, in ne enkratno dejanje, zato ga lahko označimo tudi kot filozofijo oziroma usmeritev izobraževalne institucije, za katero se je odločila in v skladu $\mathrm{z}$ njo načrtno izpolnjuje zastavljene cilje.

Izobraževalne institucije za odrasle s svojo dejavnostjo zadovoljujejo potrebe v svojem okolju, in kar je še pomembnejše, potrebe in želje svojih strank tudi predvidevajo. To pomeni, da so korak naprej in le to jim zagotavlja uspeh in konkurenčnost.

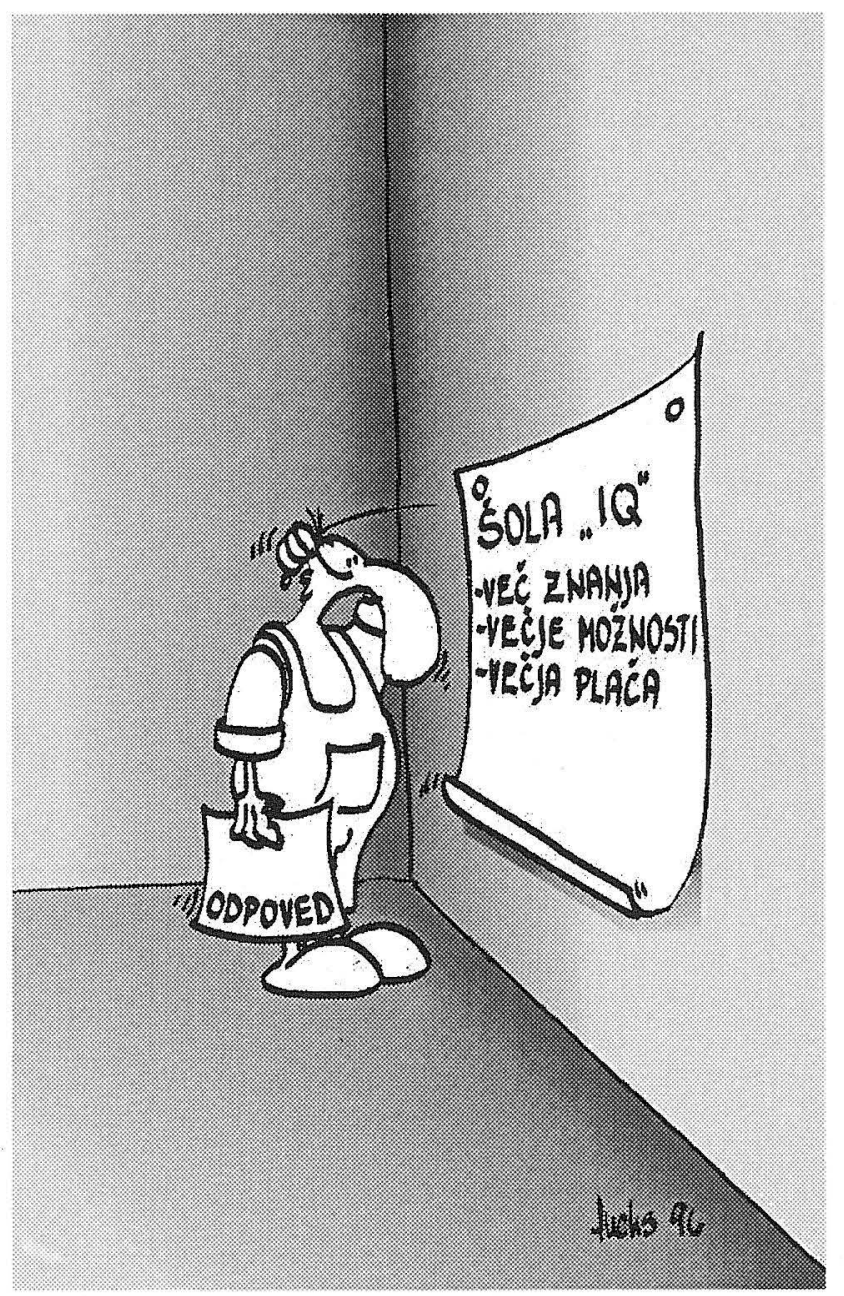

Glavne naloge marketinško usmerjene izobraževalne organizacije so določene s potrebami in $\mathrm{z}$ željami njenih ciljnih odjemalcev, pri čemer naj bi jih čim bolj strokovno zadovoljila in dolgoročno zadovoljevala njihove izobraževalne potrebe. Nekatere izobraževalne ustanove verjamejo, da bodo uspešnejše, če bodo povečale sredstva za oglaševanje in promocijo, namesto da bi razvijale nove programe, za katere je zanimanje. $Z$ vsemi mogočimi sredstvi skušajo spodbuditi ljudi, da se vpišejo v razpisane pro- grame. V kratkoročnem smislu je ta strategija lahko finančno zelo uspešna, saj je razvoj novih programov povezan z velikimi vlaganji, v dolgoročnem smislu pa je takšna institucija obsojena na propad, ker ni pravočasno predvidela novih ali spremenjenih izobraževalnih potreb in razvijala novih programov. V marketinškem izrazoslovju to pomeni, da se je menjalni proces ustavil, ker institucija ne zadovoljuje več potreb, ki se pojavljajo v okolju, v katerem deluje.

$\mathrm{Na}$ trgu se pojavljajo tudi izobraževalne organizacije, večinoma zasebne, ki ne upoštevajo osnovnega izobraževalnega poslanstva in razpišejo program, za katerega $v$ določenem trenutku sicer vlada veliko zanimanje, vendar ne zagotovijo ustrezne ravni strokovnosti. Udeležence privabijo s privlačno ponudbo in številnimi obljubami, ki pa jih seveda ne izpolnijo. Takšne organizacije, ki delujejo po načelu »take money and run« so praviloma uspešne zelo kratek čas, saj jim odjemalci, v našem primeru vedoželjni odrasli, ne zaupajo več. Naredijo pa seveda zelo veliko škode tudi drugim izobraževalnim ustanovam, ki so do svojih odjemalcev izjemno odgovorne.

Marketinško usmerjene izobraževalne organizacije morajo upoštevati štiri osnovna načela:

- izobraževalne potrebe svojih odjemalcev,

- njihove posebne želje,

- njihove dolgoročne interese,

- interese širše družbe oziroma okolja, v katerem delujejo.

Institucije, ki poznajo svoje tržišče, vedo, da se vrednote in potrebe njihovih odjemalcev spreminjajo, zato redno opravljajo marketinške aktivnosti, da bi zadovoljile svoje uporabnike.

\section{Razlogi za uporabo marketinšlkega pristopa v izobraževanju odraslih}

Obstajajo vsaj štirje razlogi, zakaj izobraževalne institucije za odrasle uporabljajo marketinški pristop:

- odrasli se prostovoljno odločajo za izobraževanje,

- prosta izbira izobraževalne institucije,

- naraščanje števila izobraževalnih organizacij za odrasle,

- možnost pridobitve dodatnega financiranja: sponzorstvo, donatorstvo, enkratna državna pomoč itd.

Na prvem mestu je vsekakor prostovoljna odločitev za nadaljnje izobraževanje. Odrasli niso zakonsko ali kako drugače prisiljeni, da se izobražujejo. K temu jih prisiljujejo predvsem zahteve razvoja in vse večje kompleksnosti življenja, ki pa se jih nekateri zavedajo, drugi pa ne. Marketinški pristop v izobraževanju odraslih pomeni seveda tudi, da izobraževalna institucija opozarja na pomen novega znanja, permanentnega izobraževanja, zastarevanje znanja, da ima podatke, ki prikazujejo izobrazbeno strukturo, zahteve prihodnosti, in še bi lahko naštevali. Vse te informacije lahko spodbudijo posameznika, da začne razmišljati o ravni svojega znanja in se odloči za vpis v določen izobraževalni program.

Odrasli se samostojno odločajo za izbiro izobraževalne institucije in jih ne moti niti večja oddaljenost od kraja bivanja, če so prepričani, da izbrana institucija in izobraževalni program ustreza njihovim pričakovanjem. Vse več odraslih se odloča tudi za izobraževanje v tujini, ker doma ne najdejo ustreznega programa ali pa o izobraževalnih možnostih niso dovolj obveščeni. Lahko se vključijo tudi v program izobraževanja na daljavo, kot ga izvajajo na primer v Avstraliji ali Kanadi, študirajo pa doma. 
Zelo pomemben razlog, ki govori v korist marketinškemu pristopu v izobraževanju odraslih, je vsekakor dejstvo, da smo v zadnjem času priča porastu izobraževalnih institucij za odrasle, ki ponujajo identične programe, med njimi pa vlada vse večja konkurenčnost. Po podatkih Zavoda Republike Slovenije za statistiko je v Sloveniji uradno registriranih 686 organizacij (d. o. o. in drugih), ki so poleg drugih dejavnosti registrirane tudi za izobraževanje. Poleg domačih organizacij in ustanov pa si v Sloveniji skušajo odrezati svoj kos tržne pogače tudi priznane tuje izobraževalne ustanove, zelo izkušene v marketinškem delovanju. Vedoželjni odrasli imajo torej zares pestro izbiro različnih institucij in izobraževalnih programov, tako da je njihova odločitev o izbiri velikokrat odvisna od bolj ali manj uspešnega marketinškega pristopa izobraževalne ustanove.

$\mathrm{Z}$ marketinškim pristopom pa bo izobraževalna institucija od donatorjev, sponzorjev in države tudi prej pridobila dodatne vire financiranja. Dodatni viri financiranja postajajo vse bolj pomembni tudi za državne izobraževalne ustanove, saj postaja vedno prazna državna blagajna pri financiranju vzgoje in izobraževanja vse manj zanesljivi vir preživetja. Sponzorje in donatorje pa si bo lahko izobraževalna institucija pridobila le, če jih bo uspela prepričati o koristnosti svojega početja in jim ponuditi nekaj $v$ zameno. Pri tem bo morala imeti trdne in zanesljive argumente, podprte s skrbno izdelanimi raziskavami trga, s poznavanjem svojega položaja med drugimi institucijami in podobno. Vse to pa si izobraževalna organizacija lahko zagotovi le $\mathrm{z}$ načrtnim in dolgoročnim marketinškim delovanjem.

Nekateri izmed navedenih razlogov veljajo tudi za redni vzgojnoizobraževalni sistem, predvsem za vrtce in srednje šole. Starši in otroci se sami odločajo za vzgojnovarstvene organizacije in izbiro srednje šole, že v osnovnih šolah pa je opazna težnja o prosti izbiri šole. Starši so pripravljeni voziti otroka v šolo tudi v drug kraj, če menijo, da bolj ustreza njihovim pričakovanjem in potrebam (Trnavčevič, 1993, str. 31). Redni vzgojnoizobraževalni sistem pa se poleg naštetih sprememb ubada še z upadanjem števila otrok, kar bo imelo za posledico zaprtje nekaterih vrtcev, osnovnih in srednjih šol.

\section{Elementi marketinga v izobraževanju odreaslih}

V Sloveniji veliko izobraževalnih institucij za odrasle že uspešno trži svoje izobraževalne programe in jim marketinško razmišljanje ne pomeni nekaj povsem novega. Med seboj se zelo razlikujejo pri uporabi sodobnih marketinških metod, tehnik in idej. Nekatere fakultete in šole so začele marketing aktivno uporabljati šele, ko so se morale sprijazniti z večjimi družbenimi sprememba$\mathrm{mi}$ in upadom števila vpisov, $\mathrm{z}$ zniževanjem proračunskega deleža, s povečano konkurenco in pojavom novih izobraževalnih potreb. Vendar pa je v marketinškem pristopu k izobraževanju odraslih tudi nekaj pasti, še posebej če želimo marketinški model prenesti iz drugih dejavnosti, na primer iz trgovine in industrije. Vedno se moramo vprašati, kaj tržimo, kako tržimo in kdo so naši odjemalci. Splošnih navodil seveda ni, je pa znanih nekaj metod, s katerimi izobraževalna institucija opravlja marketinške aktivnosti in opredeli sebe in svoj položaj v okolju, v katerem deluje.

\section{Potrebe, želje in zahreve}

Za delovanje izobraževalne institucije je poznavanje izobraževalnih potreb, želja in zahtev okolja, v katerem deluje, seveda zelo pomembno. Čeprav je izobraževalni program čisti odsev po- treb, ki smo jih spoznali v raziskavi, se lahko zgodi, da zanj ne bo dosti zanimanja. Zato se moramo poglobiti v psihologijo zadovoljevanja potreb odraslih. Kadar raziskujemo izobraževalne potrebe odraslih moramo vedeti, da se odrasli za nadaljnje izobraževanje odločajo iz najrazličnejših vzrokov. Ponavadi ločujemo med notranjimi in zunanjimi vzroki. Med notranje štejemo tiste, ki izhajajo iz posameznikove notranjosti. Posameznik preprosto začuti potrebo po dodatnem znanju in ima močno motivacijo, da se bo nekaj naučil, pridobil novo znanje ali spretnost. Zunanji vzroki izobraževalnih potreb pa izhajajo iz nečesa, kar je prišlo iz okolja in vzbudilo pozornost posameznika. V tej zvezi pogosto govorimo o zunanji in notranji motivaciji za izobraževanje.

Pri elementih marketinga pa nas bo zanimalo ravnanje in sprejemanje odločitev tistih, ki jih je $\mathrm{k}$ izobraževanju napotil njihov notranji glas, torej notranje motiviranih, in kako ravnajo tisti, ki so se odločili za izobraževanje iz nekega zunanjega razloga, iz spodbude, ki ni prišla od njih samih. Notranje motivirani posamezniki bodo sami veliko storili za to, da si bodo pridobili čim več informacij o možnostih izobraževanja, ki jih potrebujejo, da se bodo lahko odločili o svoji nadaljnji študijski poti. Iščejo samo določene informacije, ker že vedo, kaj bi radi, potrebo imajo že izoblikovano, natančno vedo, kaj hočejo, zato se morajo odločiti le še med različnimi izobraževalnimi ustanovami. Velikokrat se tudi osebno zanimajo in raziskujejo strukturo izobraževalne institucije.

Zunanji vzroki pa prihajajo iz okolja. Posameznik se lahko za izobraževanje odloči zaradi želje po izboljšanju materialnega položaja ali socialnega statusa, morda ga bo v izobraževalno središče pripeljal strah pred izgubo službe in socialne varnosti, lahko, da se je pokazala dobra priložnost, ki bi jo kazalo izkoristiti, morda so potrebe po novem znanju v podjetju, v katerem je zaposlen, lahko, da se je odločil za izobraževanje tudi zaradi pomanjkanja socialnih stikov ali pa ga je spodbudil življenjski partner, in še bi lahko naštevali. Med zunanjimi spodbudami, ki pripomorejo izobraževalni odločitvi, pa so lahko osebne ali pa neosebne. Na odločitev posameznika, da se vpiše v določen izobraževalni program, lahko vpliva enaka odločitev ali prepričevanje druge osebe, na primer partnerja, prijatelja, znanca, ki ga občudujemo, staršev, učitelja iz prejšnje šole. Neosebne spodbude, ki prihajajo iz okolja, pa so lahko oglasi, časopisni članki itd. Posamezniki, ki so zunanje motivirani, ki torej za svojo izobraževalno odločitev potrebujejo določeno spodbudo iz okolja, so po navadi veliko manj prepričani o tem, kaj resnično želijo, kaj jih veseli in kakšne so pravzaprav njihove potrebe po izobraževanju. Okolje na njih zelo močno vpliva, zato je velikokrat pomembna že prva informacija, ki jo dobijo. Zelo težko tudi izbirajo med informacijami, ki so si jih pridobili, in pogosto sprejmejo končno odločitev, ki je identična viru, ki mu najbolj zaupajo.

V tujini imajo zato izobraževalne ustanove pri obveščanju morebitnih novih študentov že dolgo tradicijo, pa ne le z obvestili ali razpisi o številu prostih mest, kakršna je praksa večine naših fakultet in višjih šol. V tujini pri tem uporabljajo aktivne metode obveščanja. Ameriški koledži pisno obveščajo vse, ki so končali »high school«. Pri tem so ugotovili, da se študentje pri izbiri koledža odločajo predvsem na štiri načine:

- nekateri, teh je malo, že dolgo pred koncem šolanja natančno vedo, kam se bodo vpisali;

- veliko se jih odloči o svoji nadaljnji študijski poti šele na podlagi posebnega vprašalnika, ki ga pripravijo šolski psihologi in pedagogi in v katerem učence sprašujejo o načrtih za prihodnost, o izbiri šole ...;

- veliko jih prisluhne mnenju prijatelja in se pridruži njegovim načrtom; 
- v nabiralniku najdejo katalog koledža s formularjem za vpis in na njegovi podlagi sprejmejo odločitev.

Vse to priča o zelo neizoblikovanih željah učencev in tudi slabi obveščenosti. Niso dovolj seznanjeni s tem, kakšne izobraževalne možnosti imajo (Kotler, 1994, str. 199).

Tudi v Sloveniji učenci, ki končajo srednjo šolo, ne poznajo dobro izobraževalnih možnosti. Po navadi je pri sprejemanju tako pomembne odločitve vključena cela družina in vsak po svoje skušajo pridobiti informacije. Učinkovito in hitro obveščanje pa je pri nas še zlasti pomembno po zadnji reformi šolstva, ko se vsako leto pojavljajo novi in novi izobraževalni programi in $\mathrm{s}$ tem nove študijske možnosti. O načinih informiranja in komuniciranja $\mathrm{z}$ javnostmi pa več $\mathrm{v}$ naslednjem poglavju.

\section{Zadovolistvo udeležencev in reševanje pritožb}

Cilj vsake izobraževalne institucije je seveda, da so udeleženci oziroma uporabniki njenih izobraževalnih storitev zadovoljni. Ljudje, ki se ukvarjajo z marketingom menijo, da je zadovoljen udeleženec najbolj učinkovito oglaševanje in ustvarjanje pozitivne podobe v javnosti. Prav zato si v izobraževalnih institucijah zelo prizadevajo, da bi bili udeleženci z njihovimi storitvami kar se da zadovoljni. Skrbijo, da izobraževalni program res izraža potrebe in pričakovanja uporabnikov, prav tako pa skrbijo za kakovostno izvedbo. Pri doseganju zadovoljstva pa uporabljajo še druge metode. Zelo dobrodošle so majhne pozornosti, ki jih študentom namenja institucija. Na primer, posameznikom čestitamo za rojstni dan, pisno se jim zahvalimo za udeležbo na tečaju, seminarju. Čestitamo jim, ker so uspešno opravili preizkusni test, ki je bil pogoj za vpis na določeno fakulteto ... S temi drobnimi pozornostmi damo udeležencu občutek, da je postal naš, da nam torej ni vseeno, kako se bo prebijal skozi študijske težave in radosti. S tem veliko pripomoremo k odprtemu in toplemu učnemu ozračju.

Če so bili udeleženci nezadovoljni z izvedbo programa, je seveda treba storiti vse, da moteče dejavnike čim prej odpravimo. Pri ugotavljanju zadovoljstva in nezadovoljstva je treba opozoriti na dejstvo, da svojega nezadovoljstva veliko udeležencev ne bo izrazilo. V številkah bi to pomenilo, da se od 27 nezadovoljnih udeležencev pritoži le eden. Bolj pogosto izražajo svoje nezadovoljstvo mlajši odrasli, starejši odrasli pa se raje tiho umaknejo in se naslednjič ne vpišejo na institucijo, s katero so bili nezadovoljni. Udeležencem je treba zato omogočiti in jih spodbuditi, da izrazijo svoje zadovoljstvo oziroma nezadovoljstvo s programom. Najbolj preprosto je, da imamo tako imenovano knjigo pripomb in pohval, kamor lahko vsakdo napiše svoje mnenje o programu in njegovi izvedbi. Na izraženo nezadovoljstvo moramo gledati kot na koristno povratno informacijo, na podlagi katere zvemo, kaj je bilo narobe in kaj je torej treba izboljšati. Nepravilnosti je treba čimprej odpraviti in o tem obvestiti vse, ki so bili nezadovoljni, kajti le tako bomo ponovno pridobili njihovo zaupanje.

Seveda pa pritožbe in izraženo nezadovoljstvo niso zanesljiv kazalec dela institucije. Na eni strani zaradi tega, ker se le malo nezadovoljnih tudi zares pritoži, na drugi strani pa zaradi »večnih nergačev«, ljudi, ki se vedno pritožujejo, ki niso nikoli z ničimer zadovoljni in kvarijo sliko o zadovoljnosti oziroma nezadovoljnosti z izobraževanjem.

\section{Okolje}

Izobraževalna ustanova ni le izobraževalni program, ki se ga posamezniki udeležijo, ampak jo v prvi vrsti predstavljajo ljudje; zaposleni, zunanji sodelavci, člani svetov, honorarni delavci, prostovoljci, donatorji itd. Izobraževalne institucije sodelujejo z zelo različnimi ljudmi, ki opravljajo različne naloge. Z vsemi pa morajo navezati in vzdrževati dobre stike in medosebne odnose.

Zaposlene po navadi predstavljajo učitelji, profesorji in drugi mentorji, ki so bolj ali manj predani izobraževalnemu poslanstvu. Učitelji zelo veliko pripomorejo h kakovosti oziroma k nekakovosti izvedbe izobraževalnega programa. Čeprav je njihova strokovnost na zelo visoki ravni, še vedno ostane vprašanje načina posredovanja tega znanja udeležencem. Včasih je način podajanja znanja celo bolj pomemben kot znanje samo. Prav zato je zelo pomembno, da se učitelji redno izpopolnjujejo v svoji stroki in širijo svoje obzorje tudi v zvezi z učinkovitimi načini prenašanja znanja in metodami motiviranja svojih učencev.

Poleg učiteljev pa zaposlené predstavlja še vodstvo institucije, organizatorji izobraževalnega procesa - andragogi, administrativno osebje - tajnica in pomožno osebje - telefonist, receptor, varnostna služba. Vsi pa morajo biti usposobljeni in motivirani za opravljanje svojega dela. Nič nam ne pomaga dober program in učitelj, če nekoga, ki se po telefonu zanima za dodatne informacije, nejevoljno odpravimo in ne zadovoljimo njegovih potreb. Razočarani interesent bo rajši poiskal drugo izobraževalno ustanovo. Veliko izobraževalnih institucij v Sloveniji ima težave $\mathrm{z}$ vedenjem zaposlenih. Vsi, ki prihajajo v kakršenkoli stik z udeleženci, bi morali biti namreč za to tudi usposobljeni. Poznati bi morali poslanstvo in cilje institucije ter po svojih močeh prispevati k uresničevanju zastavljenih ciljev. Toda le malo izobraževalnih institucij pri nas posveča dovolj pozornosti izobraževanju zaposlenih. Morda je ironija ali pa strokovna napaka izobraževalnih institucij prav v tem, da velikokrat ne vidijo lastnih izobraževalnih potreb.
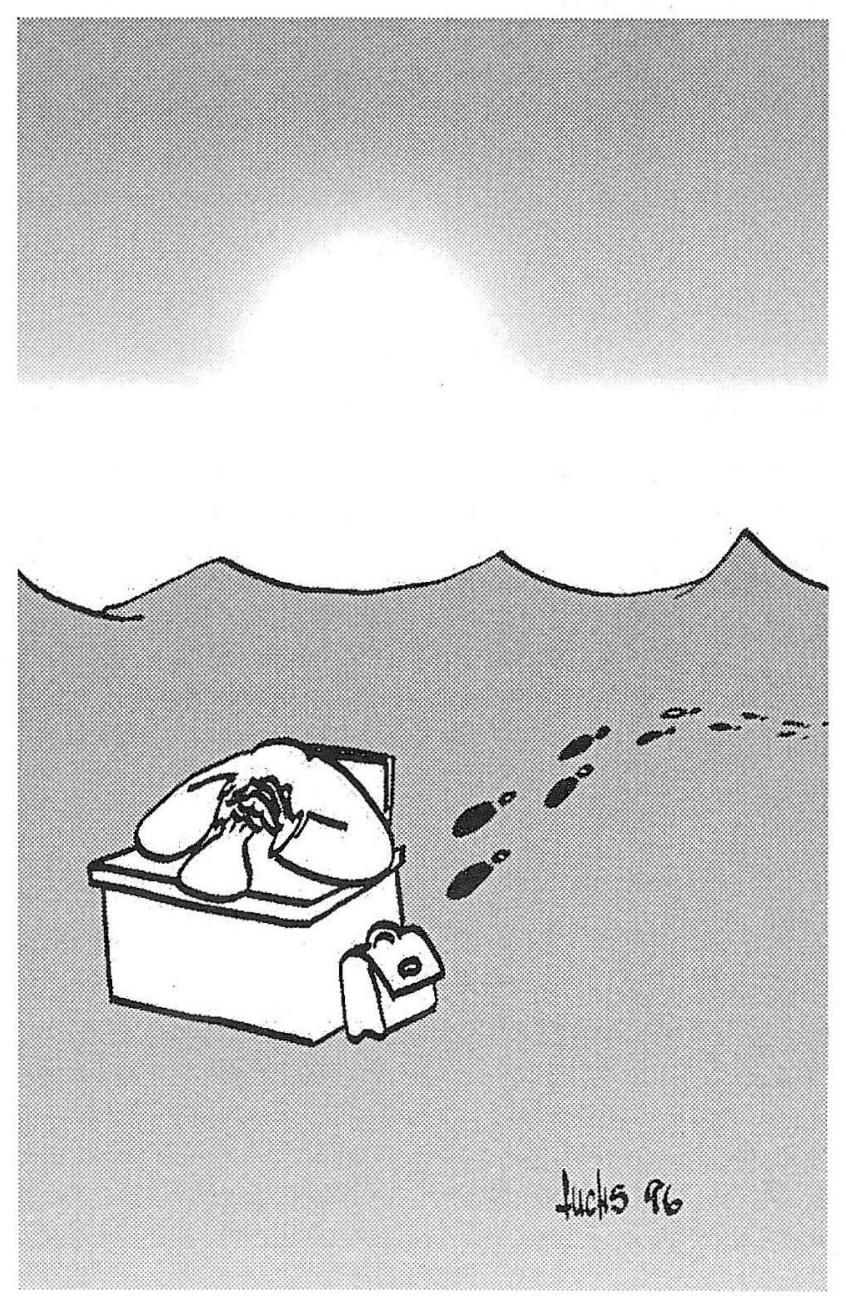
Okolje so tudi prostori, predvsem učilnice, seminarske sobe, učna oprema itd. Povsem drugače delujejo svetli in veliki prostori kakor pa temni in majhni, kjer človek hitro dobi občutek utesnjenosti. Veliko izobraževalnih organizacij za odrasle, predvsem zasebnih, nima svojih prostorov, zato najemajo prostore drugje; $v$ hotelih, občinskih zgradbah, v drugih izobraževalnih ustanovah. Čim boljše prostore imamo na voljo, tem več udeležencev bomo pritegnili, saj se v opremljenosti prostorov kaže tudi skrb za dobro počutje študentov. Prav tako je z učno opremo. Čim več opreme in čim boljšo imamo na voljo, prej bodo udeleženci dobili vtis, da se bodo $\mathrm{z}$ dobro učno tehniko naučili več in bolje.

\section{Ugled izobraževalne ustanove}

Vsaka izobraževalna institucija si prizadeva pridobiti čim večji ugled. Ta pa je zelo neoprijemljiva stvar. Velikokrat se zgodi, da si javnost ustvari napačno sliko o določeni organizaciji. Čeprav je strokovno na zelo visoki ravni, so si ljudje o njej ustvarili negativno mnenje. Določen del javnosti jo lahko občuduje, drugi del pa jo zavrača in o njej širi negativno mnenje.

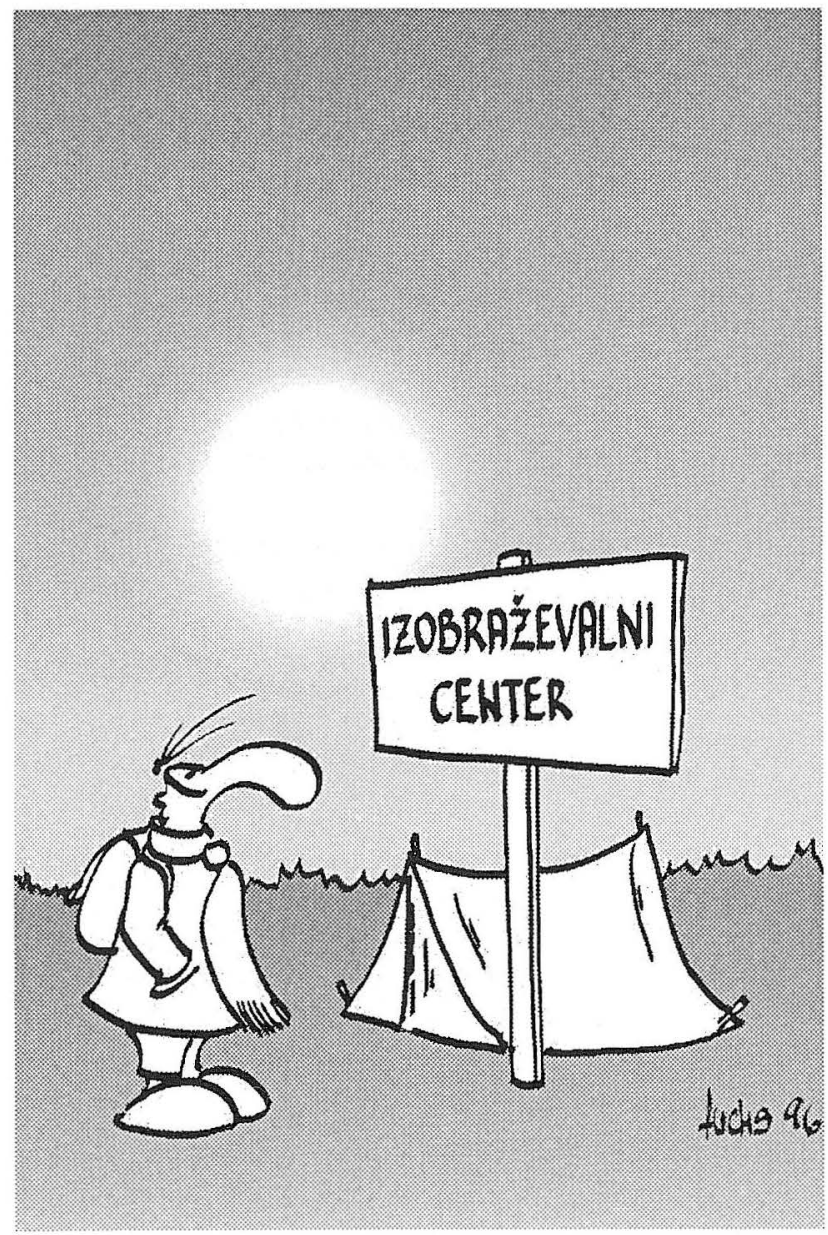

Prav je, da pri tem opozorimo na to, da se žal velikokrat dogaja, da je resnična kakovost izobraževalnih programov manj pomembna kot pa ugled institucije $\mathrm{v}$ javnosti, njene reference in prestižnost. Udeleženci, ki obiskujejo program ustanove, ki ima velik ugled, bodo verjetno imeli več uspeha pri poklicnem napredovanju ali pri kandidiranju za želeno delovno mesto, prav tako bodo lažje dobili študijski dopust in si celo pridobili štipendijo. Ugled izobraževalne organizacije seveda temelji na preteklih dogodkih, zato ga ne moremo kar čez noč spremeniti, saj izraža funkcijo njihovih preteklih dejanj in načina komuniciranja.
$\mathrm{V}$ zvezi z ugledom pogosto uporabljamo prevzeto besedo imidž. Izraz imidž je postal v svetu izredno popularen v petdesetih letih in se zelo pogosto uporablja. Velikokrat slišimo za imidž organizacije, za osebni imidž in celo imidž naroda. Za naše namene smo izbrali Kotlerjevo definicijo imidža, po kateri je »imidž skupek verovanj, idej in vtisov, ki jih ima posameznik o določenem objektu« (Kotler, 1995, str. 38). Imidž lahko tudi ugotavljamo. Najenostavnejša metoda je seveda vprašalnik, v katerem naključno izbrani vzorec ljudi sprašujemo, kako dobro poznajo določeno izobraževalno ustanovo. Odgovore lahko razvrstimo v pet stopenj:

1. nikoli nisem slišal za to organizacijo;

2. zanjo sem že slišal, vendar je ne poznam;

3. poznam jo zelo slabo;

4. poznam jo in približno vem, s čim se ukvarja;

5. poznam jo zelo dobro in vem, s čim se ukvarja.

Rezultati nam pokažejo, koliko vprašani poznajo našo organizacijo. Če večina odgovorov spada v prvi dve stopnji, potem ima organizacija resne težave glede prepoznavnosti v javnosti.

Nekdanjim in sedanjim udeležencem pa lahko zastavimo drugačno vprašanje, in sicer jih sprašujemo o tem, koliko so naklonjeni naši ustanovi in kako so zadovoljni z njo. Zopet pripravimo pet mogočih odgovorov:

1. zelo sem nezadovoljen;

2. sem nekoliko nezadovoljen;

3. sem indiferenten;

4. sem kar zadovoljen;

5. sem zelo zadovoljen.

Če večina odgovorov spada v prvi dve kategoriji oziroma prve tri kategorije, potem lahko z zanesljivostjo trdimo, da ima ustanova velike težave s svojim ugledom.

Idealno bi bilo, če bi izobraževalna ustanova raziskala vsebino svojega ugleda, saj lahko z dobljenimi rezultati določi svoje mesto med drugimi in pripravi načrt za izboljšanje svoje celostne podobe. Za to pa so seveda enostavne metode ugotavljanja ugleda premalo. $V$ nadaljevanju bom predstavila metodo semantične diferenciacije, s katero lahko ugotavljamo ugled organizacije, ki nam veliko pove tudi o vsebini ter kvaliteti dela izobraževalne ustanove. Najprej pripravimo skupek relevantnih dimenzij, za katere menimo, da jih naši udeleženci poznajo in jih lahko ocenjujejo. Dimenzije razvrstimo v petstopenjske ocenjevalne lestvice.

Fiktivne rezultate, dobljene na podlagi metode semantične diferenciacije, ponazorimo $\mathrm{z}$ naslednjo skico:

\section{B A}

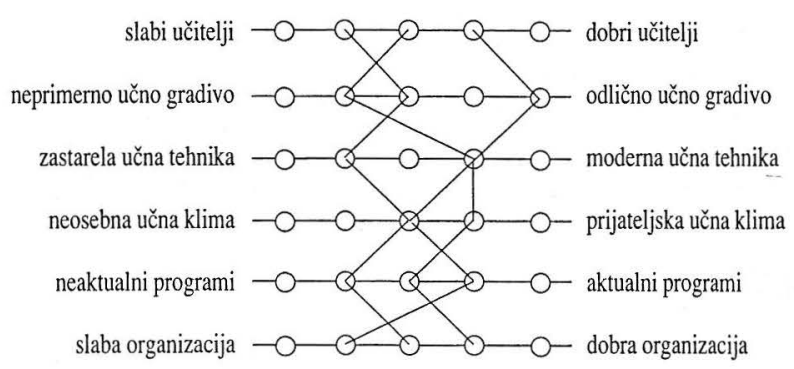

Slika 1: Ponazoritev metode semantične diferenciacije 
Izobraževalna ustanova A ima prednost glede dobrih učiteljev in učnega gradiva, težave pa ima $\mathrm{z}$ učno klimo in organizacijo. Ustanova B ima moderno učno opremo in slovi po ugodni učni klimi, izboljšati pa mora učno gradivo in bolje usposobiti svoje učitelje. Ustanova $\mathrm{C}$ je v našem primeru v najslabšem položaju, saj je znana po slabih učiteljih, zastareli učni tehniki, pa tudi njeni programi so med najmanj aktualnimi.

Če boste raziskovali ugled po tej metodi, se vam lahko zgodi, da bodo rezultati raziskave povsem drugačni od vaših predvidevanj. Za izboljšanje ugleda pa je potrebno sodelovanje vseh zaposlenih v organizaciji, zato ne bo odveč nasvet, da je v tem primeru najbolje s sodelovanjem vseh zaposlenih ustvariti podobo, ki si jo želijo in jo dejansko lahko tudi dosežejo. Nato pa podobo želenega ugleda primerjamo s sliko dobljenih rezultatov.

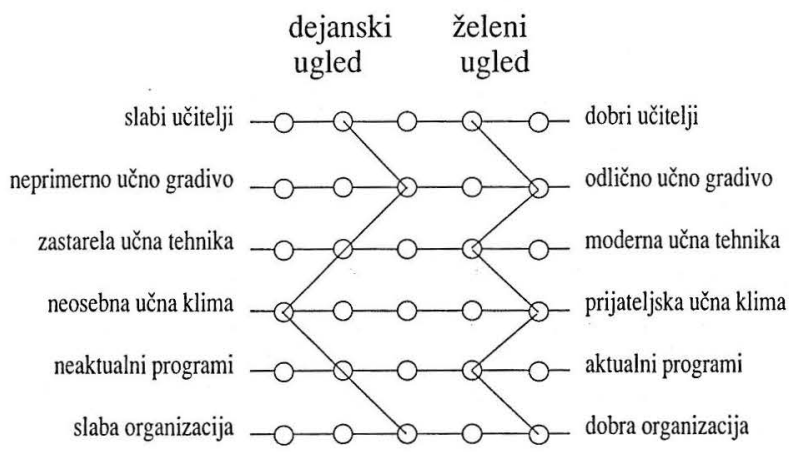

Slika 2: Razlika med dejanskim in želenim ugledom, pridobljena $\mathrm{z}$ metodo semantične diferenciacije

V ustanovi menijo, da bodo lahko najhitreje izboljšali svoj ugled, če bodo več pozornosti posvetili pripravi dobrega učnega gradiva, vnesli ugodnejšo učno klimo in izboljšali organizacijo, ne morejo pa takoj dodatno usposobiti učiteljskega kadra, posodobiti učne tehnike ter razviti novih programov.

Uspešnost izobraževalne ustanove je odvisna od tega, kako dobro zadovoljuje izobraževalne potrebe ljudi na področju, na katerem deluje. Raziskava ugleda je za institucijo dejansko mnenje javnosti o njej. Na tej osnovi se potem odloči za ustrezno strategijo izboljšave ugleda, ki je vedno povezan $\mathrm{z}$ dvigom kvalitete izobraževalnih storitev. O načrtovanih spremembah se odločamo torej na podlagi dobljenih rezultatov analize pričakovanj in potreb ciljnih skupin ustanove.

\section{Raziskave izobraževalnih potreb in tržnega vedenja}

Izobraževalne potrebe je treba raziskovati ves čas, ker se izredno hitro spreminjajo. Nekatere popolnoma izginejo in se povsem spremenijo, nekatere pa se zelo spremenijo, zato je treba izobraževalne programe posodobiti. Znanje izredno hitro zastareva, že v dveh letih, glede na informacijsko revolucijo pa lahko sklepamo, da se bo ta čas hitro skrajševal. Pojavljajo se tudi nove izobraževalne institucije, ki uvajajo nove in privlačne programe, makroekonomske spremembe narekujejo nove izobraževalne potrebe itd. Prav zato je raziskovanje izobraževalnih potreb, zahtev in želja osrednja in najbolj pomembna marketinška aktivnost. Tako kot vsak drug izdelek ali storitev je tudi izobraževalni program odvisen od zakonitosti življenjskega ciklusa ali krivulje. Življenjski cikel izobraževalnega programa je sestavljen iz štirih stopenj, to so predstavitev, rast, zrelost in upad.

1. Stopnja predstavitve označuje obdobje počasne rasti, kar pomeni, da smo program šele predstavili trgu. Tudi zanimanje

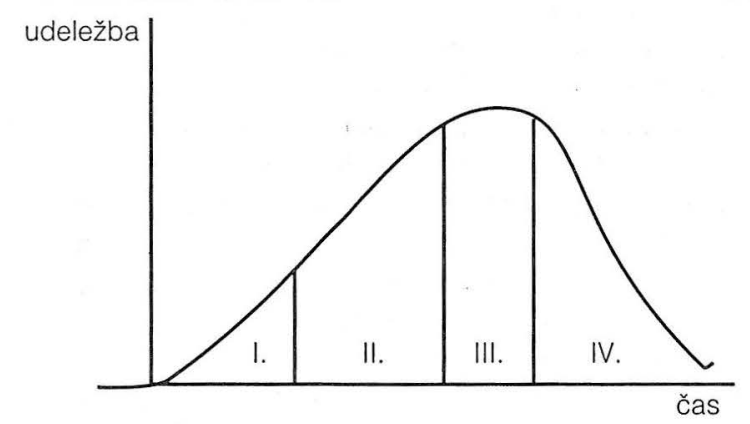

Slika 3: Življenjski cikel izobraževalnega programa

zanj še ni veliko, ker javnost o njem še ni dobro obveščena. Zato mora izobraževalna institucija za informiranje javnosti in za predstavitev programa vložiti veliko sredstev. V tem obdobju se še ne srečuje s konkurenčnimi izobraževalnimi organizacijami.

2. Stopnja rasti označuje obdobje povečanega zanimanja za izobraževalni program, če je ta seveda uspešno prešel prvo stopnjo. Institucija ima vedno večji vpis. Zaradi velikega zanimanja se tudi druge institucije odločijo za izvedbo tega uspešnega izobraževalnega programa in na trgu se pojavi konkurenca. Zato se institucije v tem obdobju trudijo, da bi izboljšale program in ga izpopolnile na osnovi izkušenj, ki so jih pridobile, prav tako pa iščejo nove ciljne skupine, ki bi bile $\mathrm{z}$ manjšimi prilagoditvami programa zainteresirane zanj.

3. Za stopnjo zrelosti je značilno le rahlo nihanje vpisa. Udeležba je pri vsaki ponovitvi skorajda enaka. Po navadi je to obdobje najdaljše. Sčasoma se na trgu pojavlja čedalje več institucij, ki izvajajo enak program, kar povzroča prezasičenost in trd boj za udeležence. Prav tako pa se tudi izobraževalne potrebe hitro spreminjajo, kar se kaže v postopnem upadu vpisa, ki je zanesljiv kazalec, da izobraževalni program prehaja v zadnjo stopnjo, to je v stopnjo upada.

4. Upad je lahko hiter ali počasen. Poleg spremenjenih izobraževalnih potreb je seveda še mnogo razlogov, ki so pripeljali izobraževalni program na zadnjo stopnjo življenjske krivulje. Morda institucija ni upoštevala posebnih potreb in želja svojih udeležencev, morda je zaradi tehničnih in drugih sprememb izobraževalni program postal povsem nepotreben ali nekoristen, in še bi lahko naštevali. Nekateri programi bodo na tej stopnji izločeni, nekatere bodo izvajali morda še na geografsko oddaljenem področju, kjer se še pojavljajo potrebe po njem, nekateri pa bodo korenito dopolnjeni in prilagojeni novim potrebam.

Sprotne raziskave izobraževalnih potreb $\mathrm{v}$ izobraževanju odraslih izvajamo predvsem na podlagi štirih metod. Obstaja jih seveda še več, vendar jih zaradi omejene rabe na tem mestu ne bom naštevala.

\section{Evalvacija}

Z evalvacijo že izvedenih izobraževalnih programov (tečajev, seminarjev ...) lahko institucija pridobi zelo pomembne informacije, ki jih lahko uporabi za dopolnitev in izboljšanje programov. Evalvacije ne smemo zamenjati $\mathrm{z}$ aktivnim opazovanjem ali celo akcijskim raziskovanjem, pri katerih so v raziskavo aktivno vključeni vsi udeleženci in se napake odpravljajo že sproti. Evalvacija izobraževalnega programa pomeni pravzaprav zbrano mnenje vseh udeležencev o istem izobraževalnem programu.

Evalvacija nam omogoča pridobitev predvsem naslednjih informacij:

- kako je program potekal - splošen vtis o izobraževalnem programu; 
- kaj so udeleženci v programu pogrešali;

- na katerih področjih se še želijo izpopolnjevati in pridobivati novo znanje;

- kako so svojo nalogo opravili učitelji.

Splošen vtis o izobraževalnem programu nam lahko pove marsikaj. Morda je udeležence motila razporeditev prostora ali klimatska naprava, morda so program obiskovali ljudje z zelo različnim predznanjem, morda jih je motil hrup v sosednjem prostoru ali pa zamujanje udeležencev ... Splošne vtise je vredno zbrati, saj bomo po več izvedenih evalvacijah gotovo opazili, da se določena mnenja in pripombe pogosteje pojavljajo. Na njih moramo biti pozorni in nepravilnosti seveda odpraviti.

Evalvacija nam tudi pove, kaj so udeleženci še pričakovali, pa jim program tega ni dal. Na podlagi zbranih informacij o tem, kaj so v programu pogrešali, se program dopolnjuje, širi in se tako prilagaja spremenjenim izobraževalnim potrebam.

Velikokrat se zgodi, da udeleženci pri obiskovanju enega izobraževalnega programa začutijo, da jim manjka znanje še na drugih področjih. Zbrane informacije o tem, na katerih področjih se še želijo izpopolnjevati, pa so nove izobraževalne potrebe in izhodišče za razvoj novih izobraževalnih programov, seveda če tako pridobljenih izobraževalnih potreb ne zadovoljuje že kateri izmed sedanjih programov institucije.

Pri evalvaciji se ocenjuje tudi učitelje, saj so ti izjemno pomemben del programa. Zbrane ocene nam povedo, kdaj moramo učiteljem pomagati, jim omogočiti dodatno usposabljanje, izpopolnjevanje $\mathrm{v}$ tujini, jim predstaviti najnovejše metode poučevanja, omogočiti dopust ali jim zaradi ponavljajočih se napak predlagati drugo delovno mesto.

$\mathrm{Z}$ metodo evalvacije dobimo torej veliko več kot le vpogled v nove izobraževalne potrebe. $Z$ naslednjimi metodami pa določamo predvsem potrebe, želje in zahteve morebitnih uporabnikov storitev v izobraževalni ustanovi.

\section{Anketni vprašalnik}

Izobraževalna institucija pripravi anketni vprašalnik, v katerem sprašuje po izobraževalnih potrebah $\mathrm{z}$ določenega področja, na primer prava, ekonomije ... Dobro urejena baza podatkov ji omogoča, da anketni vprašalnik pošlje želeni ciljni javnosti. To metodo pogosto uporabljajo, ker ne zahteva velikih stroškov. Seveda pa mora biti anketni vprašalnik dobro sestavljen in mora vsebovati takšna vprašanja, katerih odgovore bomo lahko obdelali. To pomeni, da moramo pri pripravi anketnega vprašalnika določiti tudi metodologijo obdelave, če želimo, da bodo rezultati uporabni. Slaba stran te metode pa je majhna odzivnost. Anketni vprašalnik vrne od 6 do 12 odstotkov vprašanih, zato moramo pripraviti zelo velik vzorec, da bi si zagotovili reprezentativnost.

\section{Telefonski intervju}

Manj pa izobraževalne ustanove uporabljajo metode telefonskega intervjuja, ker zahteva veliko časa, dodatno najemanje delovne sile, ustrezno opremljene prostore, tako imenovane telefonske govorilnice, razpoložljive telefonske zveze, zato je povezana $\mathrm{z}$ večjimi stroški. Je pa zelo uporabna metoda, če želimo pridobiti informacije o novih izobraževalnih potrebah $\mathrm{v}$ zelo kratkem času. Dobra stran te metode je tudi v tem, da spraševalec lahko vprašanemu vprašanja natančno razloži, če jih ta ni dobro razumel. S telefonskim intervjujem pridobimo po navadi zelo izčrpne informacije, kar pomeni, da poleg tega, po čemer sprašujemo, zvemo še nekaj več. Tako pridobljene informacije so zelo dragocene, saj jih z drugimi metodami, na primer $\mathrm{z}$ anketnim vprašalnikom ne dobimo.

\section{Osebni intervju}

Osebni intervju je najbolj prilagodljiva metoda določanja izobraževalnih potreb, pri katerem lahko iz intervjujanca »izvlečemo«, kar nas zanima. Velikokrat se zgodi, da posameznik misli, da potrebuje določeno znanje, toda ko ga presenetimo z podvprašanjem, ugotovimo, da potrebuje nekaj povsem drugega ali da celo ne ve, kakšna vsebina se skriva za posameznimi naslovi. Prav tako lahko obogatimo rezultate raziskave, ki jo delamo $\mathrm{z}$ metodo osebnega intervjuja $z$ osebnimi opažanji. Pri osebnem intervjuju lahko spremljamo reakcije intervjujanca, opazimo lahko, da se je pri nekaterih vprašanjih počutil neprijetno, da je pri določenih vprašanjih rabil več časa za razmislek, da se je spet pri nekaterih vprašanjih zelo razgovoril ali zmedel ... Intervjujanec ima tudi tukaj možnost, kakor pri telefonskem intervjuju, zahtevati pojasnitev vprašanja. Ta metoda je med vsemi opisanimi metodami povezana $\mathrm{z}$ največjimi stroški, zato jo slovenske izobraževalne institucije za odrasle skorajda ne uporabljajo. Je pa zaradi navedenih razlogov zelo zanesljiva, kar pomeni, da dobimo podatke, ki so dejansko odsev realnega stanja. Z njimi lahko zelo natančno določimo izobraževalne potrebe ter na tej osnovi razvijemo izobraževalni program, ki bo zelo blizu konkretnim potrebam, zahtevam in željam ljudi v okolju, $v$ katerem izobraževalna ustanova deluje.

\section{Informiranje in komuniciranje $\mathbf{z}$ javnostmi}

Javnost oziroma vsaj določen del javnosti mora biti informiran o dejavnosti institucije, o njenih izobraževalnih storitvah, vrstah programov itd. Šele ko je posameznik seznanjen s podrobnostmi lahko sprejme odločitev, katera institucija in kateri program je primeren zanj. Pri informiranju javnosti nas še posebej zanima:

- koliko informacij je potrebno, preden posameznik sprejme odločitev in

- katere vire informacij uporablja.

Ljudje se zelo razlikujemo med seboj po načinu sprejemanja odločitev. Nekateri se lahko odločijo v trenutku, drugi pa potrebujejo mesece, da sprejmejo osebno odločitev. Po navadi je potrebno več časa, kadar se posameznik odloča o vpisu v daljši (večletni) program izobraževanja, in manj časa, kadar se odloča za obisk enodnevnega seminarja v domačem kraju. Čim pomembnejša je odločitev za posameznika, več časa potrebuje zanjo. Nekateri se odločijo na podlagi prve informacije, ki jo dobijo, še posebej če zaupajo izobraževalni ustanovi, od katere so prejeli informacijo o izobraževanju. Drugi pa si naredijo pravi načrt in si želijo pridobiti čim več informacij o določenem izobraževalnem programu. Informacije različnih institucij med seboj primerjajo in se šele nato odločijo.

Ljudje smo pri obveščanju o izobraževalnih storitvah izpostavljeni zelo različnim virom informacij, vprašanje pa je, katere uporabljamo in katere ne. Virov informacij pri izobraževanju odraslih je seveda zelo veliko, na splošno pa jih lahko delimo v štiri večje skupine:

1. osebni in nenadzorovani vir informacij,

2. osebni in nadzorovani vir informacij,

3. neosebni in nadzorovani vir informacij,

4. neosebni in nenadzorovani vir informacij.

V nadaljevanju bomo opisali glavne značilnosti različnih virov informacij in v zvezi $z$ njimi več spregovorili o tistih virih, ki jih izobraževalne uștanove najpogosteje uporabljajo, da bi o svoji dejavnosti obvestile želeno ciljno javnost. 


\section{Osebni in nenadzorovani viri informacii}

Kadar govorimo o osebnih in nenadzorovanih virih informacij, imamo v mislih tako imenovano »ustno izročilo«. Informacijo dobimo od prijatelja, znanca, sodelavca, zakonskega partnerja, ki se je bodisi že udeležil določenega izobraževalnega programa bodisi se ga namerava udeležiti in si je že pridobil pisne informacije. Ta vir informacij je zelo pomemben, kajti osebnemu viru informacij pogosto bolj zaupamo in se odločamo na podlagi njegovih dobrih oziroma slabih izkušenj. Raziskava TARB (Technical Assistance Research Program, Washington, D. C.) je pokazala, da vsak udeleženec seminarja oziroma tečaja, ki je imel slabe izkušnje in s kvaliteto izobraževalnih storitev ni bil zadovoljen, to sporoči še 16 osebam, prijateljem, znancem itd. Trinajst odstotkov udeležencev pa to sporoči kar 20 ljudem (Gorman, 1995, str. 154).

\section{Osebni in nadzorovani viri informacii}

Med osebne in nadzorovane vire informacij štejemo predvsem tiste informacije, ki jih daje usposobljena oseba, andragog ali organizator izobraževanja po telefonu zainteresiranim posameznikom ali pa se dogovori za obisk in posamezniku skuša osebno svetovati pri njegovi izobraževalni odločitvi.

\section{Neosebni in nadzorovani viri informacii}

Najširša skupina informacij so neosebne in nadzorovane informacije, med katere prištevamo vsa pisna vabila, prospekte, kataloge, reklamne tiskovine, oglase in sporočila po Internetu in na CD-ROM-ih.

Izobraževalne institucije za odrasle $\mathrm{z}$ morebitnimi udeleženci svojih izobraževalnih programov najpogosteje komunicirajo po pošti. Pošiljajo jim vabila za seminarje, tečaje, konference in podobno. Angleški izraz za tovrstno dejavnost, ki se je uveljavil tudi pri nas, je »mailing«, uporabljajo pa ga predvsem ljudje, ki se ukvarjajo $\mathrm{z}$ marketingom. Prednost »mailinga« je, da natančno vemo, kakšne informacije bodo posamezniki prejeli, $\mathrm{z}$ dobro urejeno bazo podatkov pa tudi, kdo vse bo te informacije dobil. Nesmiselno bi bilo namreč pošiljati vabila kar počez. Prvi pogoj za izbiro tega načina komuniciranja je skrbno urejena baza podatkov, ki omogoča razpošiljanje vabil in prospektov poimensko na naslov posameznikov.

Poimenske baze podatkov, ki vsebujejo različne karakieristike o posamezniku, tako imenovani seznami mailing, so postali $\mathrm{v}$ zadnjih nekaj letih zelo priljubljeno marketinško sredstvo izobraževalnih ustanov. $\mathrm{Z}$ bazo podatkov lahko dobimo tudi zelo pomembne informacije o naših nekdanjih in sedanjih udeležencih in o novih tržnih priložnostih. Prav tako lahko z ažurirano bazo podatkov opravljamo kvalitetne marketinške raziskave. Recimo, če lahko baza podatkov posebej prikaže udeležence zadnjih dveh let, ki so starejši od 55 let, torej starejše odrasle, in če se njihovo število med udeleženci povečuje, je najbrž utemeljeno razmišljati o razvoju novih programov za starejše odrasle in jim posvetiti več pozornosti kot pa drugim aktivnostim. Priporočljivo je, da baza podatkov vključuje leto zadnjega obiska vsakega udeleženca oziroma njegove udeležbe $\mathrm{v}$ izobraževalnem programu, interesno področje, torej to, s čim se posameznik ukvarja, predvsem v prostem času, njegov spol, njegovo starost (pri starosti je bolje, da vpeljete stopnje, na primer 20-30 ali 40-50 ali več kot 50 let, kajti nekateri ne bodo želeli vpisati natančnega števila let), poklicno področje, kot na primer finance, marketing ..., organizacijo, v kateri je zaposlen, in število vseh zaposlenih $v$ tej organizaciji ter seveda natančen naslov s poštno številko. To omogoča dobro urejenim bazam podatkov dostop do podatkov o tem, kakšna je bila stopnja vpisa oziroma udeležbe na posameznih geografskih področjih. Zbrane informacije bodo omogočale izobraževalni ustanovi, da natančneje opredeli svoje udeležence, naredi tako imenovani profil svojih strank, kar ji v mnogočem olajša odločitve o izbiri in razvoju novih izobraževalnih programov.

Način »mailing « ima seveda tudi slabosti. Živimo v času, ko je v našem nabiralniku vsak dan več reklam, vabil in obvestil, zato je treba izbrati pravo pot, da bo naše vabilo zares doseglo tistega, ki mu je namenjeno. Večina takšnih oglasov in vabil namreč roma v koš, ne da bi jih ljudje sploh preleteli, kaj šele prebrali. V Ameriki vsak državljan v poprečju dobi na leto kar 200.000 vabil, prospektov, letakov, radijskih in televizijskih oglasov in reklam, kar zagotovo presega človekove zmožnosti sprejemanja različnih informacij (Draves, 1995, str. 56). O tem bi bilo zanimivo narediti raziskavo tudi v Sloveniji.

Način mailing seveda ni poceni, še posebej, če želimo narediti dober in učinkovit prospekt. V svetu se zato nekatere izobraževalne institucije odločajo za tri vrste »mailinga za isti izobraževalni program. Najkakovostnejše prospekte pošljejo svojim najboljšim porabnikom, malo manj kakovostne vsem tistim, ki so morda porabniki kakšnih drugih storitev njihove ustanove, najmanj kakovostne, ki so tudi najcenejši, pa tistim, ki se še nikoli niso udeleželi nobenega izobraževalnega programa, so pa najštevilčnejši. Pri tem načinu razpošiljanja prospektov in vabil so opazili, da z najboljšim prospektom pridobijo od 50 do 70 odstotkov udeležbe, $\mathrm{z}$ drugim najboljšim od 20 do 30 ter s cenenim prospektom od 10 do 20 odstotkov udeležbe (Draves, 1995, str. 54).

Pri načinu mailing je pomembno tudi to, kdaj ga pošljemo, zgodaj ali pozno. Če ga pošljemo prezgodaj, tvegamo, da bodo ljudje na dogodek že pozabili, če pa ga pošljemo prepozno, pa tvegamo, da ljudje ne bodo imeli dovolj časa za odločitev (ali pa ga sploh ne bodo imeli) ali pa ne bodo uspeli pravočasno uskladiti in načrtovati službenih ter osebnih obveznosti. Že na začetku poglavja smo omenili, da se ljudje razlikujemo pri sprejemanju odločitev, eni potrebujemo več, drugi manj časa, kar je odvisno tudi od oblike in trajanja izobraževalnega programa. Raziskave $v$ svetu kažejo, da se za udeležbo na dvodnevnem seminarju kar 6 odstotkov ljudi odloči tri mesece pred izvedbo, 56 odstotkov mesec dni prej, 36 odstotkov dva tedna pred izvedbo in 2 odstotka teden dni prej ali pa kar zadnjo minuto (Draves, 1995, str. 56).

Med neosebne in nadzorovane informacije štejemo tudi časopisne oglase, radijska obvestila in televizijske reklame. Tudi njihovo vsebino določa izobraževalna institucija. Časopisni oglasi so po navadi zelo dragi, zato je seveda treba vedeti, v katerih časopisih bomo z oglaševanjem dosegli našo ciljno skupino. Bolj učinkovit kot časopisni oglas je članek v časopisu, bodisi o dosežkih izobraževalne institucije bodisi o novem izobraževalnem programu. Ta način velja med ljudmi za manj vsiljivega, zato je tudi bolj učinkovit.

Radijska obvestila dosežejo najširšo množico ljudi, zato so po navadi zelo učinkovita. V poprečju Slovenci poslušamo radio štiri ure na dan, v primerjavi z Američani, ki ga poslušajo »le« tri ure na dan (Batt, 1995, str. 38).

Radio tudi ni prostorsko omejen, poslušamo ga v službi, doma, $\mathrm{v}$ avtomobilu itd. Izbrati moramo le pravo frekvenco, še posebej zato, ker je za radijske poslušalce značilno, da so med najbolj zvestimi izbrani radijski postaji. Radio je najbolj fleksibilno sredstvo oglaševanja in podajanja informacij in je seveda »kompatibilen« $\mathrm{z}$ vsemi drugimi sredstvi informiranja.

Le redko pa slovenske izobraževalne institucije kot sredstvo za obveščanje morebitnih udeležencev uporabljajo televizijske oglase, saj je tovrsten način obveščanja med najdražjimi. Za gotovo pa je med zelo učinkovitimi, saj vključi še vizualno komponento spre- 
jemanja pri posamezniku in pritegne pozornost $\mathrm{z}$ gibljivo sliko. Veliko ponudb in razpisov izobraževalnih programov pa se pojavlja na teletekstu, ki je veliko cenejši in je pomembno informacijsko

Slika 4: Poslušanost radia v Sloveniji - januar '96

Povprečje dnevne poslušanosti v minutah

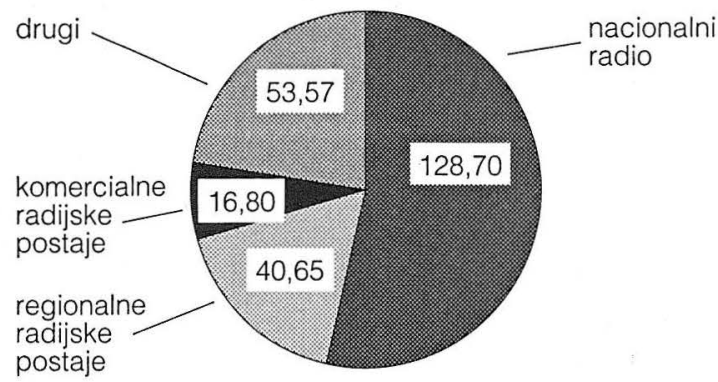

(vir: Facts about Slovenia, Mass Media, januar 1996)

sredstvo. Po zadnji raziskavi, ki je bila narejena marca 1996, spremlja informacije na teletekstu slovenske nacionalne televizije 16 odstotkov vseh njenih gledalcev (Facts about Slovenia).

$\mathrm{V}$ zadnjih nekaj letih pa se je zelo razmahnila svetovno povezana računalniška mreža Internet, ki pomeni pravo revolucijo $v$ informacijsko-komunikacijskih sistemih in je zelo poceni ter učinkovita možnost podajanja informacij. V Sloveniji se Internet šele razvija, toda po prvih podatkih o porastu števila slovenskih uporabnikov Interneta lahko sklepamo, da bo že v zelo bližnji prihodnosti pomemben informacijski vir.

\section{Neosebni in nenadzorovani viri informacii}

To so vse tiste informacije, na katere izobraževalna institucija ne more vplivati in jim ne določa vsebine. Med te informacije štejemo razna poročila in članke $v$ množičnih javnih občilih in vse nepredvidene dogodke, ki jih ne moremo napovedati. Za primer vzemimo, da se neka časopisna hiša odloči narediti tematsko prilogo o izobraževanju odraslih in v njej opiše tudi dejavnost vaše izobraževalne ustanove.

Morebitni udeleženec je seveda izpostavljen različnim virom informacij. Če se informacije iz različnih virov, ki jih je posameznik prejel, dopolnjujejo, obstaja veliko večja možnost, da se bo odločil za vpis v izobraževalni program. Če pa si informacije iz različnih virov nasprotujejo, pa bodo prejemniki informacij zmedeni in bodo menili, da je institucija neodgovorna. Zelo pomembno je, da vemo, katerim virom je izpostavljena ciljna javnost, ki jo želimo informirati o naših izobraževalnih storitvah, kajti le tako lahko izberemo najbolj optimalen način obveščanja. Da bi to izvedeli, pa moramo najprej narediti raziskavo o tem, katerim virom informacij so izpostavljeni naši udeleženci.

\section{Sklepne misli}

Trženje v izobraževanju in trženje izobraževalnih storitev obstaja, s tem se namreč strinjajo tudi priznani avtorji, kot so Kotler, Gray in Armstrong. Nesmiselno bi si bilo zatiskati oči pred dejstvom, da je znanje postalo cenjeno tržno blago in da se je zato, kot velja tudi za vsako drugo tržno blago, podredilo zakonitostim marketinškega delovanja. S pričujočo razpravo sem skušala pokazati, da marketinške aktivnosti v ustanovah, ki se ukvarjajo z izobraževanjem odraslih v Sloveniji, že obstajajo in da bodo postajale čedalje pomembnejše. Pri ljudeh, ki se ukvarjajo z izobraževanjem odraslih, še vedno prevladuje negativna predstava o marketingu, kot o nečem, kar je $\mathrm{v}$ neposrednem nasprotju $\mathrm{z}$ osnovnim poslanstvom izobraževalnih institucij, to je prenašanje znanja, oblikovanje celostne osebnosti in podobno. Toda razlog za negativne predstave je predvsem slabo poznavanje in razumevanje marketinga. Marketing v izobraževanju odraslih je povezan predvsem $\mathrm{z}$ raziskovanjem izobraževalnih potreb, želja in s predvidevanjem morebitnih potreb, $\mathrm{z}$ namenom, da bi lahko institucija pravočasno razvila kakovostne izobraževalne programe. Tako razumljen marketing pa lahko le pripomore $\mathrm{k}$ razvoju in h kakovosti izobraževanja odraslih.

Cilj vsake izobraževalne ustanove je pridobiti čim več udeležencev, kar pa lahko uresničijo z doslednim upoštevanjem marketinških elementov, med katerimi sem $v$ razpravi še posebej poudarila zadovoljevanje potreb, želja in zahtev uporabnikov izobraževalnih storitev, skrb za njihovo zadovoljstvo in dobro počutje med izobraževanjem, usposobljenost in motiviranost zaposlenih v izobraževalni organizaciji ter ustvarjanje pozitivnega ugleda $v$ javnosti oziroma okolju, v katerem organizacija deluje. Uspešnost izobraževalne ustanove pa je odvisna tudi od načina komuniciranja z javnostmi ter od obveščanja morebitnih uporabnikov izobraževalnih storitev. Nič nam ne pomaga še tako dober izobraževalni program, če ljudje ne vedo, da obstaja. Javnost mora biti najprej dobro seznanjena $\mathrm{z}$ možnostmi izobraževanja, različnimi izobraževalnimi vsebinami in različnimi načini pridobivanja znanja. Šele te informacije posamezniku omogočijo, da sprejme individualno študijsko odločitev. Marketing kot obveščanje pravzaprav izpolnjuje osnovno demokratično poslanstvo, ki se glasi: pravica vedeti.

Navodil za pravilno ravnanje pri trženju izobraževalnih storitev, ki se danes kaže kot nujno, pa seveda ni. Velikokrat prihaja tudi do napak, zlorab in poskusov manipulacije z ljudmi. Zaradi tega se vse bolj pojavljajo tudi dileme o etičnosti trženja v izobraževanju. Nekaj pa za gotovo drži. Čim bolje bomo poznali teorijo trženja in njene konkretne aplikacije in izpeljave, lažje se bomo lahko izognili velikim zmotam. To nas učijo tudi izkušnje v državah, ki so se s trženjem v izobraževanju srečale že mnogo prej.

\section{Daniela Brečko}

raziskovalka na Gospodarskem vestniku, d. d.

\section{Litergfura}

Batt, D. (1995): Making Radio Work for You, Session handout in LERN International Conference on Lifelong Learning Programming, San Antonio, 7-9 December.

Bottery, M. (1992): The Ethics of Educational Management, Cassel Educational Ltd.

Draves, W. A. (1995): Building Your Marketing Database, Session handout in LERN International Conference on Lifelong Learning Programming, San Antonio, 7-9 December.

Draves, W. A. (1995): Target Marketing, Session handout in LERN International Conference on Lifelong Learning Programming, San Antonio, 7-9 December.

Facts about Slovenia, Mass Media, januar 1996, Media Research Institute, Ljubljana.

Gorman, T. J. (1995): Costumer Service in the 1990s, Session handout in LERN International Conference on Lifelong Learning Programming, San Antonio, 7-9 December.

Gray, I. (1991): Marketing in Education, Open University Press.

Morello, G. (1993): The Hidden Dimensions of Marketing, Journal of the Market Research Society, Vol. 35, No. 4.

Kotler \& Anderson (1995): Strategic Marketing for Nonprofit Organisations, Prentice Hall.

Kotler \& Fox (1992): Strategic Marketing for Educational Institutions, Prentice Hall.

Likosar, J.: Marketinški prijem izobraževañja na Srednji frizerski šoli v Ljubljani, Vzgoja in izobraževanje.

Trnavčevič A. (1994): Trženje v izobraževanju - ne, hvala, Vzgoja in izobraževanje.

Trnavčevič A. (1994): Trženje v izobraževanju in etika, Vzgoja in izobraževanje. 